\title{
New ants (Hymenoptera: Formicidae: Dolichoderinae) from Canadian Late Cretaceous amber
}

\author{
RYAN C. MCKeLLAR, JAMES R.N. GLASIER \& MiCHAEL S. ENGEL
}

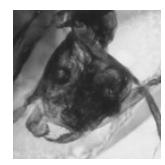

\begin{abstract}
A new genus and species are described within the ant subfamily Dolichoderinae (Formicidae). Chronomyrmex medicinehatensis gen. et sp. nov. McKellar, Glasier \& Engel provides a solid example of Dolichoderinae within the Campanian Grassy Lake amber of southern Alberta (Late Cretaceous, 78-79 Ma). The new species fills a void in the dolichoderine fossil record left by Eotapinoma canadensis Dlussky, a putative dolichoderine whose taxonomic placement has been questioned, and whose type material has been lost. As such, C. medicinehatensis provides a constraint for divergence times of the subfamily and Leptomyrmecini, one of its recently resurrected tribes. This discovery greatly extends the proposed divergence time for Dolichoderinae, and likely Leptomyrmecini, to more than $78 \mathrm{Ma}$ - contrary to some of the more recent estimates inferred from molecular phylogenies. Key words: fossil Hymenoptera, Aculeata, Campanian, Grassy Lake amber, divergence times.
\end{abstract}

MCKellar, R.C., GlasieR, J.R.N. \& ENGEL, M.S. 2013. New ants (Hymenoptera: Formicidae: Dolichoderinae) from Canadian Late Cretaceous amber. Bulletin of Geosciences 88(3), 583-594 (4 figures). Czech Geological Survey, Prague. ISSN 1214-1119. Manuscript received February 28, 2013; accepted in revised form May 10, 2013; published online June 10, 2013; issued July 3, 2013.

Ryan C. McKellar (corresponding author), Division of Entomology (Paleoentomology), Natural History Museum, and Department of Ecology \& Evolutionary Biology, 1501 Crestline Drive - Suite 140, University of Kansas, Lawrence, Kansas 66045, USA; and Department of Earth and Atmospheric Sciences, University of Alberta, 1-26 Earth Sciences Building, Edmonton, Alberta, T6G 2E3 Canada; ryan.mckellar@ku.edu・James R.N. Glasier, Department of Renewable Resources, 814 General Services Building, University of Alberta, Edmonton, Alberta, T6G 2H1, Canada; jglasier@ualberta.ca・Michael S. Engel, Division of Entomology (Paleoentomology), Natural History Museum, and Department of Ecology \& Evolutionary Biology, 1501 Crestline Drive - Suite 140, University of Kansas, Lawrence, Kansas 66045, USA; msengel@ku.edu

Ants are a dominant group in a wide array of modern terrestrial settings (Hölldobler \& Wilson 1990), but in the Mesozoic, they did not yet display the kind of diversity and abundance that we experience today. The sparse and sporadic fossil record of the family within the Cretaceous suggests that the group originated in the Early Cretaceous, and that their major diversification and rise to ecological dominance took place in the Palaeogene, likely within the Eocene (Grimaldi et al. 1997, Grimaldi \& Agosti 2000, Ward 2007, Perrichot et al. 2008). Within most Cretaceous amber deposits, ants are a minor component of the assemblage. The greatest abundance of ants reported to date has stemmed from Ethiopian amber (likely Cenomanian in age, 3\% of inclusions), but this is almost certainly a sampling artifact, as only 30 arthropod inclusions have been reported from the site (Schmidt et al. 2010). All of the larger and more extensively studied Cretaceous assemblages have been characterized by a low percent abundance of formicids, with the Charentese (Albian-Cenomanian) and Baikura (Late Cretaceous) ambers containing $1.2 \%$ and $1.6 \%$ ants, respectively, and other deposits containing less than $1 \%$ formicids: Burmese amber (Early Cenomanian, 0.2\%), New Jersey amber (Turonian, $0.05 \%$ ), Yantardahk, Siberian amber (Santonian, 0.001\%), Canadian amber (Campanian, 0.03\%) (Dlussky 1975, Rasnitsyn \& Kulicka 1990, Grimaldi et al. 2000, Grimaldi \& Nascimbene 2010, Perrichot et al. 2010, McKellar \& Engel 2012, LaPolla et al. 2013, and references therein). This contrasts strongly against the abundance of formicids in Palaeogene ambers (e.g., Baltic amber, Middle-Late Eocene, 5\% of inclusions) and even more so against their Neogene record (e.g., Dominican amber, Early Miocene, 24-36\% of inclusions), where they are a major component of the assemblages (Grimaldi \& Engel 2005, Dlussky \& Rasnitsyn 2007, LaPolla et al. 2013). This general trend should be interpreted with some caution, particularly in the Cretaceous, because of our limited understanding of the ecological controls on each amber assemblage. Even among coeval Palaeogene deposits, formicid abundance varies for unknown reasons, or due to the degree to which each deposit has been investigated (A. Nel, pers. comm.). 
The formicids in Cretaceous amber deposits represent a mixture of extinct formicid subfamilies such as Sphecomyrminae and Brownimeciinae, found alongside less numerous representatives of the extant subfamilies Dolichoderinae and Formicinae, and possible examples of Ponerinae and Aneuretinae (Engel \& Grimaldi 2005, LaPolla et al. 2013). Canadian amber provides a typical Cretaceous assemblage, in terms of both abundance and subfamily representation (Pike 1995, Grimaldi \& Agosti 2000, Engel \& Grimaldi 2005). Formicid species described from Canadian amber include: Sphecomyrma canadensis Wilson (Sphecomyrminae, $\mathrm{n}=2$ ); Eotapinoma macalpini Dlussky (Dolichoderinae, $\mathrm{n}=1$ ); Canapone dentata Dlussky (?Ponerinae, $\mathrm{n}=1$ ); Cananeuretus occidentalis Engel \& Grimaldi (?Aneuretinae, $\mathrm{n}=2$ ). Recently, there has been resurgence in interest in the ants within the assemblage, with descriptions of two putative Aneuretinae (Engel \& Grimaldi 2005), a new haidomyrmecine (Sphecomyrminae) specimen (McKellar et al. 2013), and further study of $S$. canadensis (Borysenko, in prep.).

Canadian amber provides an important glimpse into formicid evolution, because it is the last amber with a high diversity of inclusions prior to the end of the Cretaceous (Grimaldi \& Engel 2005). As such, Canadian amber captures the last records of formicid lineages that apparently went extinct near the end of the Cretaceous, and it provides some indication of standing diversity during the early part of the formicid radiation. It figures prominently in the fossil record of dolichoderines, because it was the source for the first Mesozoic representative of the subfamily, E. macalpini. However, the taxonomic placement of Eotapinoma has subsequently been questioned (Grimaldi \& Agosti 2000, Ward et al. 2010). Unlike Kyromyrma neffi Grimaldi \& Agosti (from New Jersey amber), which displayed a clear acidopore and obviously belongs within the crown group formicid subfamily Formicinae (Grimaldi \& Agosti 2000), much of the support for placing Eotapinoma within Dolichoderinae relies on negative evidence. Dlussky (1999) provided a brief description and illustrated E. macalpini in a series of outline-style diagrams of habitus and key features, but from this work it was not clear that the specimen possessed a terminal slit on its gaster. Instead, the lack of a sting or acidopore was taken as an indication of affinity. As an isolated record of Dolichoderinae within the Mesozoic, the specimen has not been viewed as definitive evidence for the presence of the subfamily by all authors. With the description of another dolichoderine from Canadian amber herein, and the report of one definitive dolichoderine awaiting description from Ethiopian (Late Cenomanian) amber (Schmidt et al. 2010, LaPolla et al. 2013), it seems much more likely that Dlussky (1999) was correct in his placement of Eotapinoma.

Unfortunately, it was recently discovered that the type and only material of Eotapinoma and Canapone has been lost in Russia (A. Bennett, pers. comm.). This loss prevents the reassessment of these taxa here, meaning that we may never be certain about the placement of Eotapinoma. However, recent ant discoveries in the assemblage give some hope that replacement material may eventually be recovered. In a recent screening of approximately 440 inclusion-bearing pieces of amber (collected by M. Elaschuk), at least three definitive formicids were recovered (pers. obs.). This suggests that the occurrence rate of the family may be somewhat closer to $1 \%$ than previous work has indicated (Pike 1995, Dlussky \& Rasnitsyn 2002, Perrichot et al. 2008, McKellar \& Engel 2012, LaPolla et al. 2013) although there is a chance that this increased abundance may just be an artifact of working with a smaller collection.

Originally this study was to review the entirety of Formicidae within Canadian amber. As it turns out, all other curated specimens have been lost, were being studied, or had just been described in work on the bizarre, trap-jawed sphecomyrmine belonging to Haidomyrmecini (McKellar et al. 2013). This means that the entire assemblage consists of the three UASM specimens described herein, the two TMP specimens of $C$. occidentalis (Engel \& Grimaldi 2005), the two CNCI-CAS specimens of $S$. canadensis currently under re-examination (Borysenko, in prep.), and a single UASM specimen of Haidomyrmecini that was recently described. The main drawback of this situation is that it is not possible to compare new material to the lost collections, and it will not be possible to reassess the phylogenetic placement of controversial taxa, such as Eotapinoma (Grimaldi \& Agosti 2000, Ward et al. 2010). Hopefully, these specimens will be recovered or replaced, so that they can be included in more comprehensive future investigations.

\section{Geological background}

Canadian amber was first reported at the end of the $19^{\text {th }}$ century (Tyrrell 1892), and was among the first Cretaceous deposits to be studied for insect inclusions (Carpenter et al. 1937). Canadian amber was formed approximately 78-79 million years ago, when cupressaceous trees living along the margins of the Western Interior Seaway released resins that were trapped in the sediments of a nearby salt marsh or lagoon. These sediments underwent diagenesis, and ultimately became part of the Taber Coal Zone within the Upper Cretaceous Foremost Formation. The uppermost coal seams of the Taber Coal Zone are now exposed in a series of abandoned pit mines in southern Alberta, creating a surface concentration of inclusion-bearing amber in the vicinity of the Grassy Lake hamlet (full locality and collecting details for the Grassy Lake site are available to qualified researchers through the Royal Tyrrell Museum of Palaeontology). Additionally, a secondary deposit of 
Canadian amber is present along the shores of Cedar Lake, in western Manitoba, as a result of the South Saskatchewan River system incising some of the same strata that contain "Grassy Lake amber". The correlation between deposits, biodiversity of inclusions, and full details of the geological setting for Canadian amber have recently been reviewed (vide Pike 1994, 1995, McKellar et al. 2008, McKellar \& Wolfe 2010). Hymenoptera inclusions have also been reviewed in detail (vide McKellar \& Engel 2012). All formicids that have been recovered from Canadian amber have been collected from the Grassy Lake site, not the secondary Cedar Lake deposit, so their age and provenance are firmly established.

\section{Material and methods}

Specimens were prepared using standard techniques for fragile amber specimens (e.g., Nascimbene \& Silverstein 2000). The resulting epoxy-embedded amber pieces were slide mounted and polished to obtain thin sections, and these were observed with an Olympus SZX12 stereomicroscope, and supplemented with compound microscopy on an Olympus BX51 or Zeiss Axio Imager A1 (for dark field microscopy). Photomicrographs were obtained with a $\mathrm{Ca}$ non EOS 7D camera attached to an Infinity K-2 longdistance microscope. Measurements were obtained using an ocular micrometer. The image series generated through stereo- and compound microscope photomicrography were subjected to focal plane enhancement with Helicon Focus software. In order to make this work more accessible, terminology largely follows the generalized hymenopteran set of Goulet \& Huber (1993), with clarifications for taxon-specific terms. Those terms unique to Formicidae stem from Hölldobler \& Wilson (1990) and Bolton (1994), and many pertinent to this work are well-illustrated in the works of Keller (2011) and Yoshimura \& Fisher (2011).

Institutional abbreviations. - CNCI-CAS - Canadian National Collection of Insects and Arthropods - Canadian amber series, Ottawa, Ontario, Canada; TMP - Royal Tyrrell Museum of Paleontology, Drumheller, Alberta, Canada; UASM - University of Alberta Strickland Entomology Museum, Edmonton, Alberta, Canada.

\section{Systematic palaeontology}

Family Formicidae Latreille, 1809

Subfamily Dolichoderinae Forel, 1878

Comments. - Overall, the new fossil matches well with the current concept of Dolichoderinae. Although current material does not allow us to observe features such as the com- plete closure present between the metacoxal cavities and the petiolar articulation, or the anterior emargination of the helcium's dorsal surface, all other observable diagnostic characters (sensu Shattuck 1992; Bolton 1994, 2003) are present. These characteristics include: the attachment between the helcium and gaster occurring low on the first gastral segment; the possession of a small pygidium, and the possession of an apical slit between the pygidium and hypopygium (no acidopore or sting is present and a froth of small bubbles originates from this gap in the type specimen's gastral apex). It is unclear whether the feature is taphonomic (the result of perimortem contraction) or morphological, but the pygidium also appears to be retracted beneath the penultimate tergite, which was noted by Bolton (2003) as characteristic of some dolichoderine genera. Furthermore, the fossils display the "dolichoderine face" proportions and compound eye placement, and bear denticles along the basal margin of the mandibles - features that Bolton (2003) indicated as typical for most dolichoderines.

\section{Tribe Leptomyrmecini Emery, 1913}

Type genus. - Leptomyrmex Mayr. Other genera included: Anillidris Santschi, Anonychomyrma Donisthorpe, Azteca Forel, Chronomyrmex gen. nov., Doleromyrma Forel, Dorymyrmex Mayr, Forelius Emery, Froggattella Forel, Gracilidris Wild \& Cuezzo, Iridomyrmex Mayr, Linepithema Mayr, Nebothriomyrmex Dubovikov, Ochetellus Shattuck, Papyrius Shattuck, Philidris Shattuck, and Turneria Forel (Ward et al. 2010, Bolton 2012).

Comments. - The value of recognizing multiple tribes within Dolichoderinae has been questioned (e.g., Shattuck 1992, 1995; Bolton 1994, 2003), but morphological (e.g., Brandão et al. 1998) and molecular (e.g., Brady et al. 2006, Moreau et al. 2006) phylogenetic analyses seem to support at least some of the groupings that were recently proposed by Ward et al. (2010). Leptomyrmecini began as a monotypic tribe proposed by Emery (1913), and although it has been variably recognized by different workers, its content underwent little change until the work of Ward et al. (2010) resurrected the taxon. In this act, they incorporated a range of genera that were recovered as a monophyletic group in their study, and that have been sporadically recovered as members of the same clade in previous molecular studies (e.g., Brady et al. 2006, Moreau et al. 2006). The tribe has yet to be subjected to any subsequent morphological or combined morphological/molecular analysis designed to test its monophyly, but it was not supported by the previous morphological analyses conducted at the appropriate taxonomic level (i.e., Shattuck 1995, Brandão et al. 1998). 


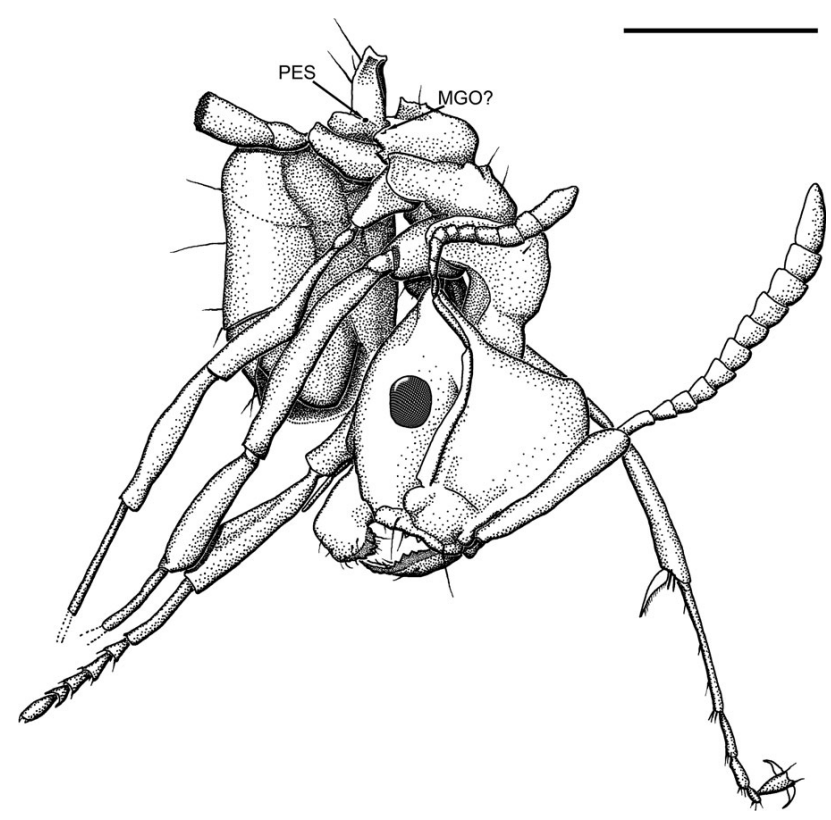

Figure 1. Chronomyrmex medicinehatensis gen. et sp. nov. habitus diagram, holotype, UASM 336801: dorsolateral oblique view. Preserved with frons and right side of head partially compressed, pronotum and propleuron partially compressed, right metafemur truncated, metasomal divisions difficult to discern because of translucent cuticle and bubble-shrouding; only conspicuous setae and clearly defined tarsomeres were figured (for clarity). Abbreviations: MGO? - metapleural gland opening (unclear); PES - petiolar spiracle. Scale bar: $0.5 \mathrm{~mm}$.

Of the diagnostic criteria provided by Ward et al. (2010) for Leptomyrmecini, all characters are present in Chronomyrmex, with the exception of the straight anteromedial margin of the mesosternum, which is simply not observable due to specimen orientation.

\section{Genus Chronomyrmex gen. nov.}

Type species. - Chronomyrmex medicinehatensis sp. nov.

Etymology. - The name is a combination chronos and myrmex, Greek terms for "time" and "ant", respectively. The name refers to the anachronistic presence of a derived dolichoderine as early as the Late Cretaceous, and it is masculine.

Diagnosis. - Compound eye comparatively dorsal in position, situated midway between posterior genal angle and posterolateral margin of clypeus; ocelli indistinct in holotype [clearly absent in paratype]; anteromedial clypeal margin slightly concave, and posterior margin extending between antennal bases, almost even with posterior margin of antennal socket (Figs 1, 2A, B); clypeal region adjacent to buccal cavity narrow (exsagittally), with straight, sub-erect seta half as long as mandible adjacent to each torulus; mandible with clear basal angle, basal margin with 4 low denticles, masticatory margin with 7 teeth and denticles distributed between teeth; apical tooth robust, nearly double length of subapical tooth; occipital margin of vertex gently concave, with subangular genae laterally; antenna 12-segmented; scape short, just reaching occipital margin, or extending slightly beyond margin; pronotum elongate, forming narrow "neck" anteriorly; metanotal sulcus broad, deep and U-shaped; propodeal dorsal prominence comprised of small, flat-topped convexity followed posteriorly by gentle slope or subtle secondary dorsal convexity with low, blunt tubercles; propodeal angle sharp, carinate, but without prominent spines; metapleural gland orifice opening laterally, and shielded laterally by guard setae; tibial spur formula 1,2,2; pretarsal claws simple and smooth; petiolar scale height comparable to dorsoventral thickness of petiolar body, and scale inclined posteriad, with dorsolateral, anterior, and posterior surfaces slightly concave, resulting in a "saddle-shaped" appearance dorsally; raised posterodorsal rim of petiolar scale bearing four or more prominent setae; gaster nearly circular in section; gastral apex slightly flattened, with apical slit (Fig. 2C); gaster with very few prominent setae widely distributed on dorsal surface.

Comments. - Chronomyrmex displays a suite of characters that suggest an affinity to a number of genera in the Leptomyrmecini, but the new genus, unsurprisingly for its age, does not match the diagnosis of any known genus. Morphological similarity is strong enough that the fossil material generally keys out to Anonychomyrma or Linepithema in the works of Shattuck (1992) and Bolton (1994), with the latter identification depending on geographic region. The new species also meets most of the updated diagnostic criteria for Anonychomyrma and Linepithema (sensu Shattuck 1992) with the exception of apparently lacking a keel-shaped fourth gastral sternite, possessing a unique petiolar scale morphology (Fig. 3A, C), and possessing an apical mandibular tooth (Fig. 3B) that is not exceptionally long (the latter character only contrasts with Linepithema). As in Anonychomyrma, the petiolar scale has roughly equal anterior and posterior surface heights, but in Chronomyrmex, the scale appears to be inclined posteriad and is

Figure 2. Chronomyrmex medicinehatensis gen. et sp. nov. photomicrographs, holotype, UASM 336801. • A - oblique dorsolateral habitus. • B - details of mandibles and clypeus, oblique dorsal view (b.f. - bright field photomicrograph), arrow indicates dorsal margin on lateral part of clypeus. $\bullet$ C - details of gastral apex, ventral view (b.f.), with arrows marking poorly visible lateral corners of gastral slit, and with minute bubbles clouding right side of apex. Preservation conditions explained in Fig. 1. Scale bars: $0.5 \mathrm{~mm}$ (A), and $0.25 \mathrm{~mm}$ (B, C). 
Ryan C. McKellar et al. • New ants from Canadian Late Cretaceous amber

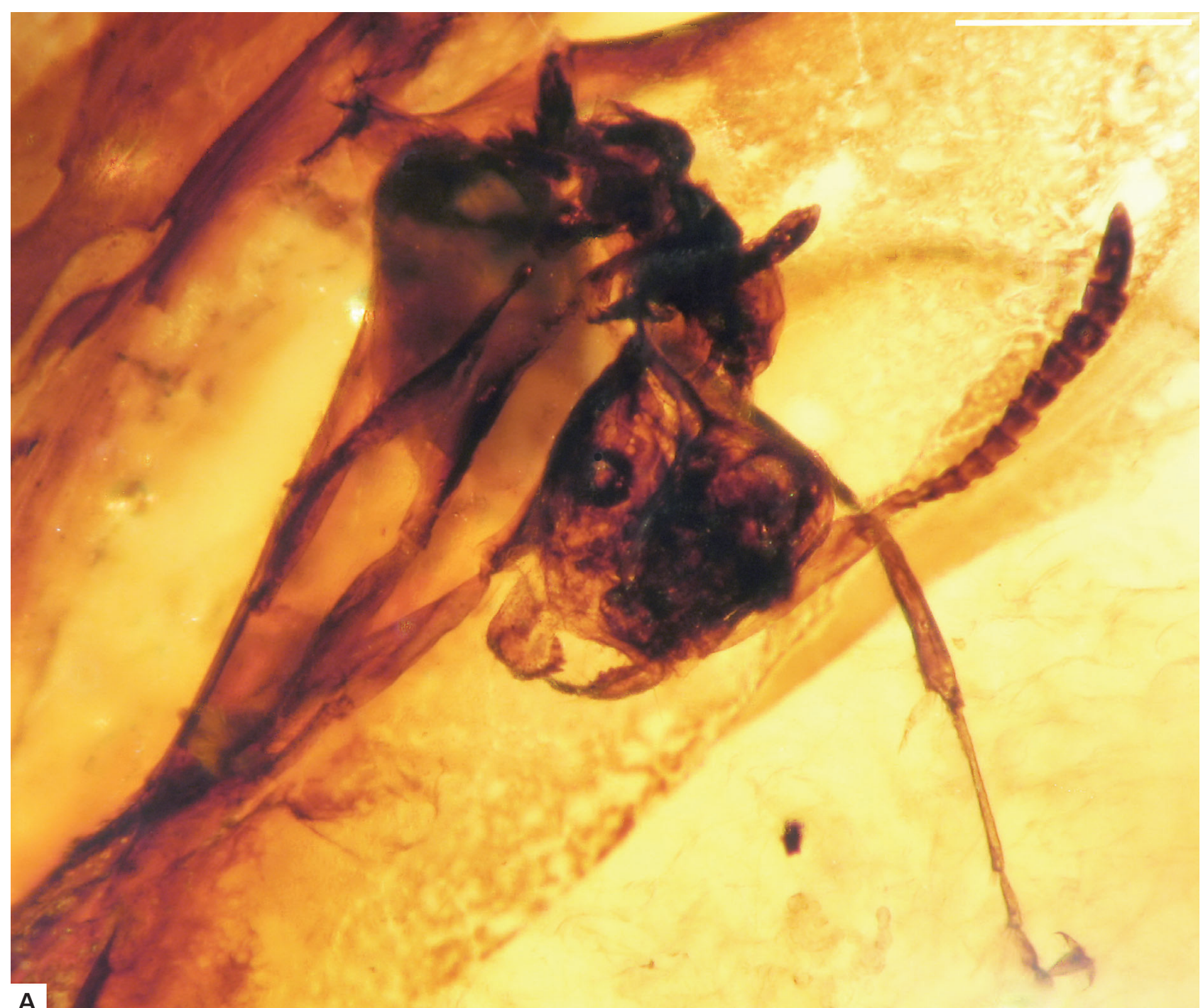

.
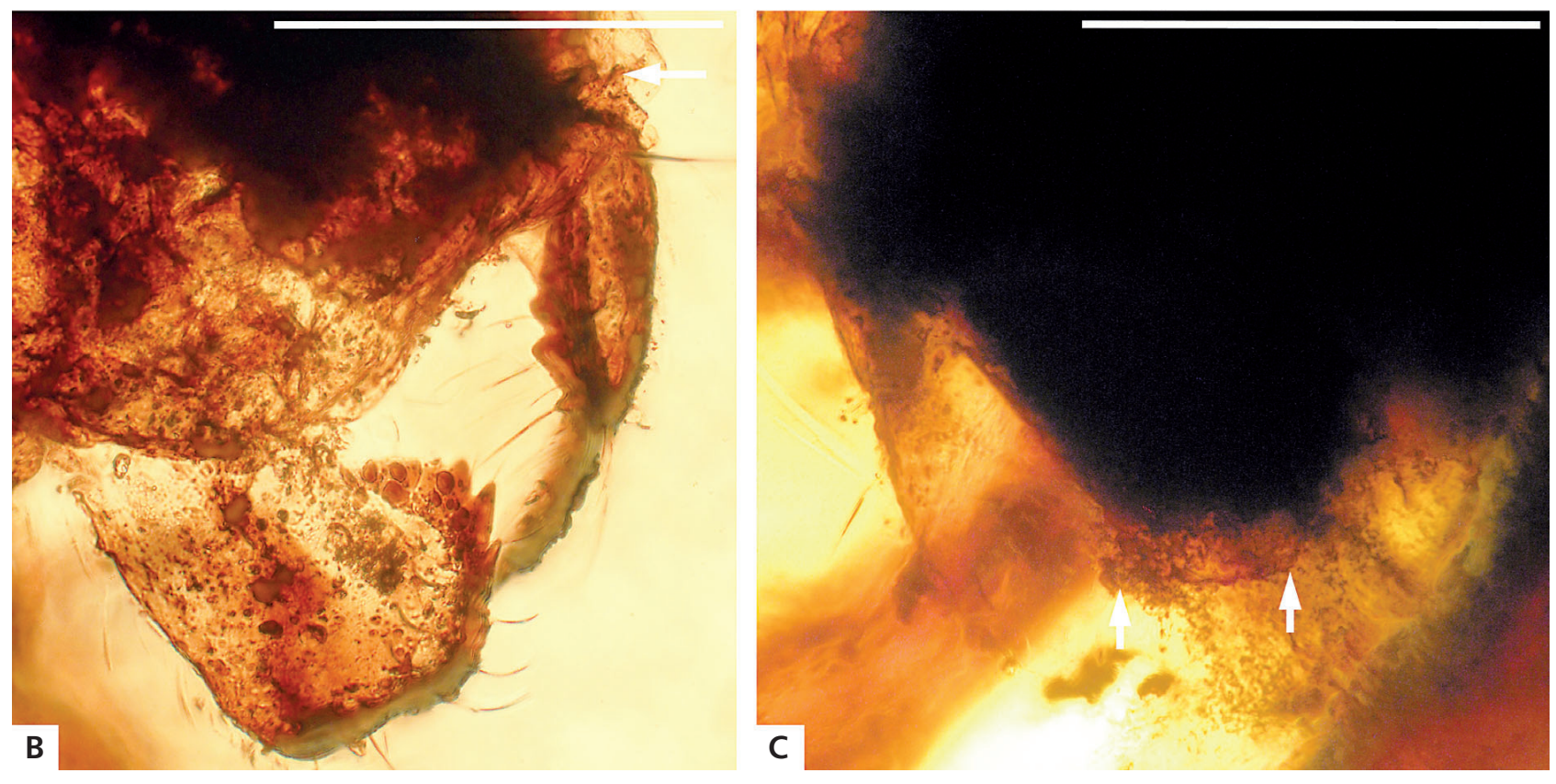
"saddle-shaped" (with recessed anterior, posterior, and dorsolateral surfaces). The "saddle-shaped" scale (Fig. 4) appears to be unique within Dolichoderinae, while its posteriad orientation is rarely encountered (e.g., Gracilidris Wild \& Cuezzo, but here the apex of the scale is simply curved posteriad). Chronomyrmex also differs from Anonychomyrma, in that its compound eyes are positioned more dorsally. It should be noted that there is a small chance that the petiolar scale shape observed in the fossils is a result of taphonomic distortion, but this seems unlikely given that the same shape was observed in two different specimens.

The slight concavity present along the anterior clypeal margin is highly characteristic of Linepithema (e.g., Shattuck 1992). In the cladistic analysis of Shattuck (1995), Linepithema and Anonychomyrma have similar coding for characters related to the worker caste. Out of 31 worker-based characters, the two genera differ in only four character states: in two of these cases, Chronomyrmex codes similarly to Anonychomyrma (it has a slightly elongate subapical mandibular tooth, and the mandibular basal angle is covered in denticles), while one character coding is more Linepithema-like (the anterior margin of the clypeus is gently concave), and the final character is not observable (the anterior tergosternal suture on gastral segment I is not visible). These two extant genera occupied basal positions within two distinct clades in Shattuck's (1995) morphological analysis, but he also noted that these particular genera were of uncertain placement and likely to mobilize in future analyses. In the expanded analysis of Brandão et al. (1998), Linepithema and Anonychomyrma were consecutively nested within the same clade, a result not retrieved in the molecular analysis of Ward et al. (2010).

Ultimately, the fossil material is confidently referred to Dolichoderinae, but despite numerous similarities, it clearly does not belong to any known genus. A phylogenetic analysis will be necessary to clarify its position relative to the known genera, but given the coding similarities to both Linepithema and Anonychomyrma, and the uncertainty that surrounds the tribal divisions within the subfamily, it is reasonable to suggest that it will likely occupy a similar position.

\section{Chronomyrmex medicinehatensis sp. nov.}

Figures 1-4

"Undescribed Formicidae". - McKellar \& Engel 2012, p. 273 , fig. 5 d.

Material examined. - Holoty pe: female, worker, UASM 336801; Late Cretaceous (Campanian) amber, Foremost Formation, Grassy Lake locality, southern Alberta, Ca- nada. Specimen trapped in drying line, partly obscured, with minor taphonomic distortion; collected and donated by Shane Leuck. Paratype: female, partial specimen, UASM 336802; Grassy Lake amber. Specimen largely undistorted, but translucent and partially disarticulated; collected and donated by Mark Elaschuk.

Etymology. - The specific epithet "medicinehatensis" refers to the collection area for the fossil material, near the city of Medicine Hat, in southern Alberta, Canada. It also acknowledges the scientific contributions of city residents, such as Shane and Vicki Leuck, collectors of the type specimen.

Diagnosis. - As for genus, by monotypy (vide supra).

Description. - Note: measurements and features observed from paratype specimen are placed within brackets. Total body length $\sim 2.4 \mathrm{~mm}$ (base of mandibles to posterior margin of petiole $\sim 1.8 \mathrm{~mm}$ ); cuticle imbricate and most body regions with pubescence. Head somewhat rectangular in outline, with posterolaterally expanded genae, and tapering anteriorly adjacent to mandibular bases, and with slightly concave occipital margin; in lateral view, posterior corner of gena appears angular, and lateral surface of gena is compressed along its posteroventral margin; including mandibles, head length $\sim 0.8 \mathrm{~mm}$ with mandibles closed $(1.1 \mathrm{~mm}$ with mandibles open); compound eyes slightly ovoid; frontal lobe prominent, but not obscuring antennal base; in both lateral and dorsal views, frontal carina prominent, and terminating in line with dorsal margin of compound eye (carina artificially elongated by compression of head in type specimen); posteromedial part of clypeus broadly convex; anteriomedial and anterolateral part of clypeus short, separated from posteromedial clypeus by broad sulcus laterally and partially overshadowed by posteromedial clypeus medially; mandibles with strong convexity along masticatory margin; only mandibular teeth and basal margin denticles clearly visible in type specimen, but paratype displays right mandible clearly (Figs 2B, 3B; counting from apex, with tooth position indicated by Roman numeral: I, II, 2 denticles, III, 4 denticles, IV, 3 denticles, V, 1 denticle VI, VII, 4 low denticles along basal margin); maxillary palp 6-segmented, poorly oriented for measurement, but apparently with apical segment longest; labial palp apparently 4-segmented, but difficult to observe; antenna geniculate and gently clavate, with bulbus large and mostly unshielded by torular lobe, and with bulbus neck (radicle) apparently subparallel to long axis of scape, but offset toward medial margin of scape; scape comparatively short, only extending beyond occipital margin by distance equal to one scape thickness (type specimen taphonomically compressed, with scape just reaching occipital margin); antennal segment II (pedicel in general hymenopteran studies) short, slightly pyriform, only as long as flagellar articles I 
and II combined; flagellar articles progressively widen, with article IX widest, and with article X marginally narrower but nearly twice as long as IX, and terminating in rounded point; antennal setae consisting of short, fine setae inclined and dense, with setae longer and more erect near apex of scape and each flagellar article. Entire head pubescent, with setae dense and ranging from inclined to erect on posterior margin of vertex and posterodorsal corner of gena. Conspicuous setae (longer and coarser) on head consist of: 1 seta on each torular lobe and near midlength of each frontal carina, setal lengths approximately double diameter of antennal bulbus; anterior margin of clypeus with 2 short, straight spicules on each lateral lobe; mandibles with sparse coat of fine mid-length setae inclined or recumbent on most surfaces - along posterior (inner) surface, setae become coarser, more dense, and longer adjacent to masticatory margin (Figs 1, 3A, 4).

Mesosoma or alitrunk long ( 0.32 of total body length) and shallow (dorsoventrally) with pronounced constrictions between its subcomponents; pronotum rapidly expanding near its midlength, with inflated dorsolateral areas and partially flattened dorsomedial region posteriorly; lateral surface of pronotum expansive and slightly concave, with subtle raised margin along posteroventral margin, and pronotum with bulbous ventral surface in this region; propleuron only visible as narrow wedge shape in lateral view, tapering anteriorly, and contributing little to "neck" region; mesonotum present as low, flat-topped prominence dorsal to posterior margin of pronotum, with dorsal mesonotal prominence offset anteriorly (with respect to episternum) by broad metanotum; distinction between mesonotum and episternum not visible, but with metathoracic spiracle visible and situated well behind anterior margin of propodeum; anterior margin of propodeum overhanging metanotum slightly; propodeal declivity with concave anterior surface, but relatively flat within posterior three-quarters of length. Mesosomatic vestiture consisting of pubescence with sporadic suberect setae ranging from moderately long to long; [distribution of conspicuous (longer setae) consisting of 5 or 6 setae on pronotal dorsal margin, 8 or more on ventral margin of propleuron, 5 or more on mesonotum adjacent to metanotal sulcus, 3 or more on propodeal dorsal prominence]; vestiture of short setae grows progressively longer on propodeal declivity; metapleural gland opening shielded by patch of ( 9 or more) long, curved, recumbent guard setae along lateral surface of propodeum. Legs fairly long and robust; procoxa large, slightly larger than episternum; profemur gently inflated towards midlength; protibia strongly inflated, with 1 protibial spur, and with 2 raised pads basal to spur, apparently for insertion of additional spines; protibial spur pectinate with covering of fine setae that increase in density apically, spur surrounded by 2 straight spines equal to one-half tibial apical width, and spur length equals double width of pro- tibia; probasitarsus with row of 6 or more short spines along ventral part of apical margin, and few inclined spines in row along length of ventral surface; tarsomeres II, III, and IV with comparable spine rows, while tarsomere V lacks spines but bears field of fine, inclined setae long enough to shroud pretarsal claws; meso- and metatarsus with similar setation and spine patterns; meso- and metacoxa significantly smaller than procoxa, and mesofemur similar to profemur in degree of inflation; mesotibia swollen apically, with only 1 apical spur clearly visible in holotype; mesotibia best observed in paratype [with 2 apical spurs, with anterior spur smooth, strongly bent, thin, and short (length equal to one-half of tibia's apical width), while posterior spur is 3 times as long, robust and slightly sinuous, with comb of stout spicules basally on inner surface, and spicules are replaced by short, fine, inclined setae within apical half, on both sides of spur]; metafemur less swollen than other femora, and metatibia less swollen than other tibiae, especially near its apex; metatibial spurs difficult to observe due to orientation, but 2 spurs of unknown length are present.

Metasoma with petiole elongate and bearing prominent scale; gaster drop-shaped in dorsal outline; at least three gastral tergites form smooth dorsal carapace, with second tergite nearly 3 times as long as first tergite; pygidium and hypopygium apparently retracted beneath apex of third tergite; divisions between gastral sternites unclear in type specimen, largely obscured by lateroventral extent of tergites; apical slit in gaster indicated by froth of fine bubbles emanating from region; prominent gastral setae comparable in length to those on petiolar scale and dorsal alitrunk surfaces.

Measurements (in $\mathrm{mm}$ ): total body length (outstretched) 2.4; head (posterior margin of head to anterior margin of clypeus) 0.58 [0.7]; outstretched mandible length [0.40]; mesosoma (alitrunk) 0.76 [0.96]; petiole 0.21 [ 0.29]; gaster 0.79 [missing]; total antenna $1.42 \mathrm{~mm}$ [ 1.6, compressed and disarticulated in paratype]; scape 0.47 [ 0.61]; antennal segment II 0.13 [ 0.14]; flagellar articles I-X (0.05, 0.06, 0.07, 0.07, 0.07, 0.08, 0.08, 0.08, $0.08,0.18$ ) [approximately $0.05,0.07 .0 .08,0.08,0.08$, $0.08,0.09, ?, 0.10,0.22]$; mandible (along anterior edge) [ 0.40]; procoxa 0.21 [ 0.29], mesocoxa 0.19 [ 0.19], metacoxa 0.20 [ 0.25], profemur 0.53 [ 0.58], mesofemur 0.52 , metafemur 0.44 , protibia 0.43 , mesotibia 0.38 [ 0.52], metatibia 0.44 , protarsomeres I-V $(0.35,0.11$, $0.09,0.05,0.10)$, mesotarsomeres I-V $(0.31,0.07,0.06$, $0.05,0.08$ ) [approximately $0.44,0.12,0.10,0.06,0.06$ ], metatarsomeres I-V $(0.31,0.10,0.07,0.06,0.09)$.

Comments. - There is a slight chance that the two specimens described under $C$. medicinehatensis may belong to different species - the paratype appears to be roughly 20 to $25 \%$ larger than the holotype in some of the dimensions 
measured. However, no structural differences have been found to support the separation of these specimens, and the paratype has undergone partial compression and substantial disarticulation. Only with additional specimens could the distribution of size ranges be interpreted and support found for the recognition of an additional species.

Family ?Formicidae

Indet. subfamily

Figure 3D

Comments. - In addition to the two specimens of C. medicinehatensis described herein, one partial, putative formicid has been discovered. UASM 336803 is a very poorly preserved individual that was trapped along a drying line within the amber, and has developed a rind of fungal hyphae that obscures most of the dorsal side, while much of the ventral side is missing as a result of preparation. The overall appearance of the specimen is highly suggestive of Formicidae, including its general body shape, "necked" pronotum, head profile, 12-segmented, geniculate antenna with a short scape (for an ant), compound eye position, and what appears to be a petiole devoid of a prominent scale. Unfortunately, informative regions such as the most of the gaster, mandibles and ventral portions of the head are missing, and most views of the head, propodeum, and petiole are all but obscured. This prohibits a confident identification, and we can only speculate as to its placement within Formicidae. The exceptionally long flagellar article I (1.5 times the length of antennal segment II) suggests that this specimen belongs within Sphecomyrminae, as it was considered by Wilson et al. (1967) and Dlussky $(1975,1987)$ to be characteristic of the subfamily.

\section{Discussion and conclusions}

Although his material is no longer available for study, it is clear from the work of Dlussky (1999) that none of the new specimens are additional representatives of Eotapinoma, the only other dolichoderine to be recovered from Canadian amber. Aside from tribe-level characteristics that distinguish Chronomyrmex from Eotapinoma, Eotapinoma clearly differs in its lack of a petiolar scale. In fact, the "saddle-shaped" scale of the new species appears to be unique within Dolichoderinae.
If Chronomyrmex belongs within Leptomyrmecini (and is not a stem group member that is somehow convergent upon the tribe's morphology), it would dramatically push back many of the divergence times recently proposed by Ward et al. (2010) and Moreau \& Bell (2013). Based on an extensive molecular analysis, Ward et al. (2010) arrived at divergence estimates (95\% CI) of 61-74 Ma for Dolichoderinae, and 49-52 Ma for Leptomyrmecini, with a cladistic nesting pattern consisting of (Aneuretinae + (Tapinomini + (Bothriomyrmecini + (Dolichoderini + Leptomyrmecini)))). The most recent estimates (Moreau \& Bell 2013) have placed the divergence of Dolichoderinae between 53.2 and 66.3 Ma. At a minimum, the new fossil material indicates that Dolichoderinae were present 78 million years ago. Furthermore, these specimens strongly suggest that Leptomyrmecini were present at this time. Given the tribe's position high within the topologies presented by Ward et al. (2010) and other studies (e.g., Brady et al. 2006, Moreau et al. 2006, Brandão et al. 1998, Moreau $\&$ Bell 2013), an extension on divergence estimates for all Dolichoderinae is required. This extension is more in line with the age estimates established by Brady et al. (2006) and Moreau et al. (2006) for Dolichoderinae (which ranged from approximately 71-76 $\mathrm{Ma}$, or accepted Eotapinoma as a 78 Ma constraint on dolichoderine divergence, respectively). The Moreau et al. (2006), Brady et al. (2006), and Moreau \& Bell (2013) studies recovered a Leptomyrmecini-like clade as one of the most derived groups within their topologies, and the basal divergence for this clade seems to occur at roughly $60 \mathrm{Ma}$ (Moreau et al. 2006, Moreau \& Bell 2013). If this particular divergence is constrained to $78 \mathrm{Ma}$ by the new fossil material, many of the nodes between must also move back in time.

Modern dolichoderines are cosmopolitan, with the greatest species richness occurring in the tropics and Australia (Shattuck 1995). In the Cretaceous, the only other record of Dolichoderinae stems from putatively Late Cenomanian Ethiopian amber (Schmidt et al. 2010, LaPolla et al. 2013). These records indicate that the subfamily was already widespread in the Cretaceous, with representatives in both Gondwana and western Laurentia. Among the modern dolichoderine genera, Chronomyrmex is most similar to Anonychomyrma and Linepithema. If this similarity reflects relationship, then it may also support a broader palaeobiogeographic pattern. Anonychomyrma is currently restricted to Australia with few representatives in the Orient

Figure 3. A-C - Chronomyrmex medicinehatensis gen. et sp. nov. photomicrographs, paratype, UASM 336802; D - indet. Formicidae photomicrographs, UASM 336803. • A - right lateral habitus. • B - details of clypeus, labrum, galea, and mandibles, same view (b.f.), with arrow marking dorsal margin on lateral part of clypeus. $\bullet$ C - details of petiole and posterior propodeum, rotated from (A), horizontal arrow indicating MGO (also, note guard setae), diagonal arrow indicating PES. Preservation conditions and abbreviations explained in Fig. 4 . $\bullet$ D - oblique ventral view, with much of legs, petiole and gaster missing; arrow indicating elongate flagellomere I. Scale bars: $0.5 \mathrm{~mm}(\mathrm{~A}), 0.25 \mathrm{~mm}(\mathrm{~B}, \mathrm{C}), 1.0 \mathrm{~mm}$ (D). 
Ryan C. McKellar et al. • New ants from Canadian Late Cretaceous amber
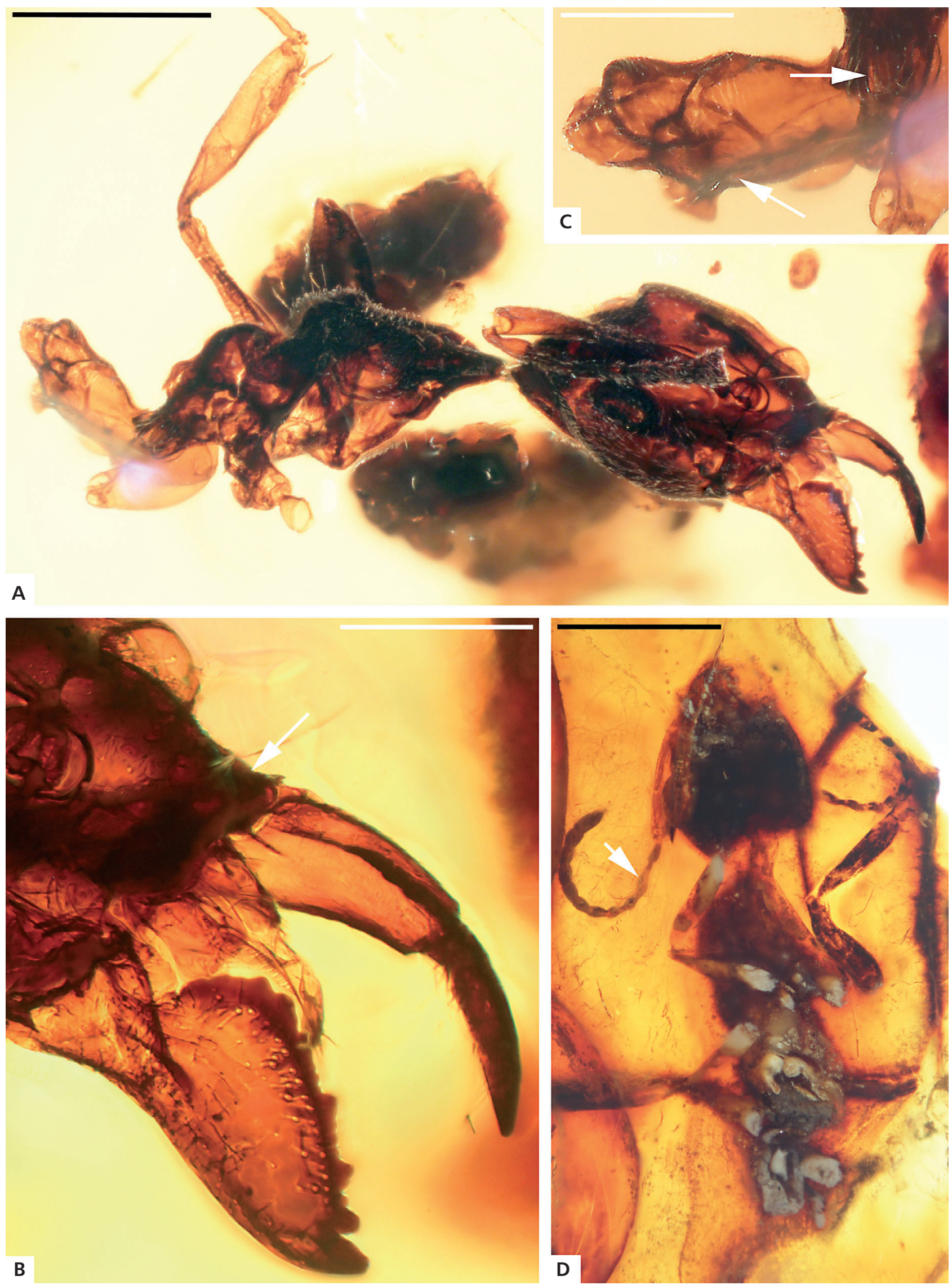


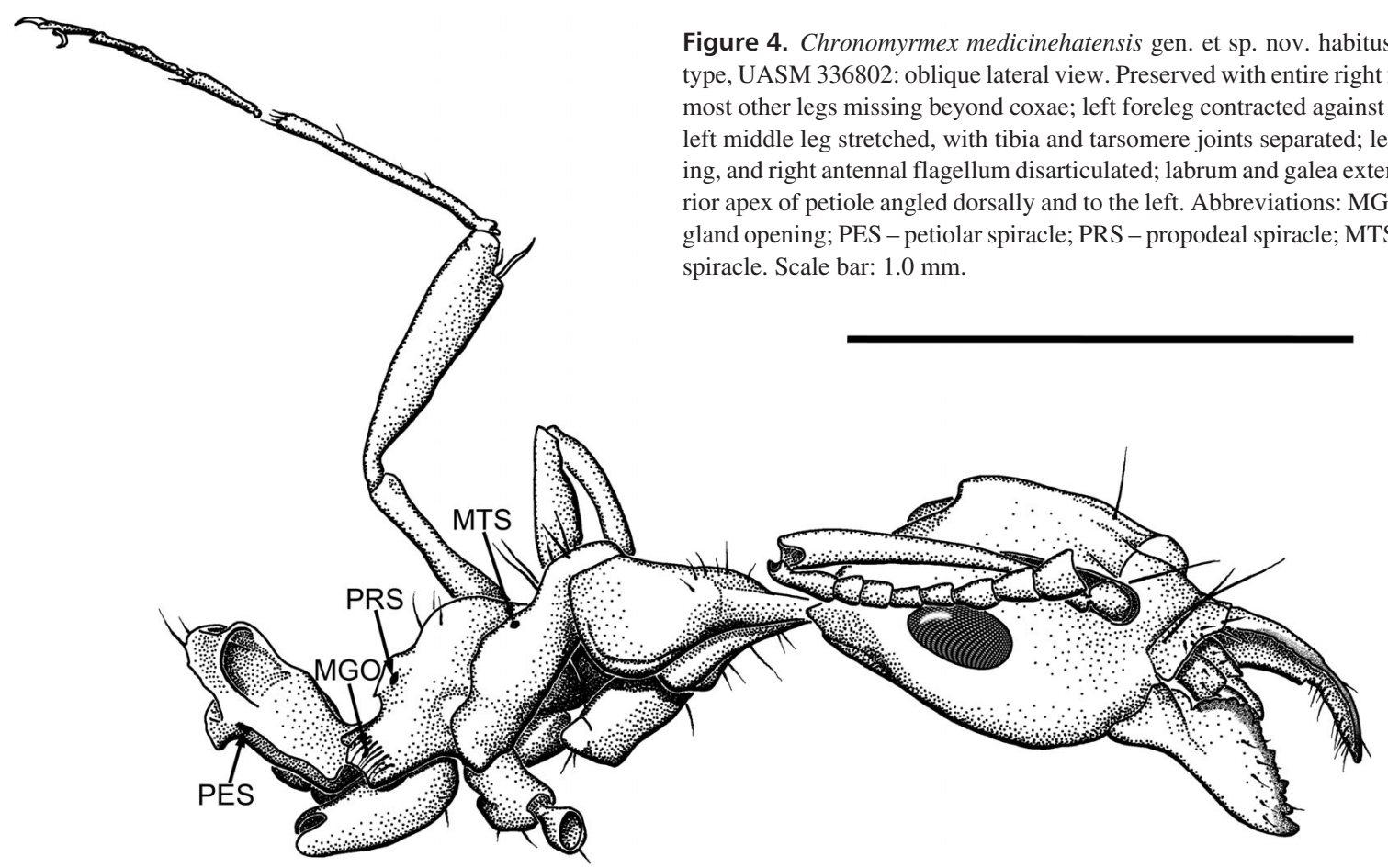

(Shattuck 1995). Ward et al. (2010) found that the clade containing Anonychomyrma appears to have shared a most recent common ancestor with Linepithema, and that the predominantly Australian distribution of the clade containing Anonychomyrma was likely the result of a colonization event out of South America around 30-28 Ma. This would have been followed by a period of isolation and diversification after the dispersal route through Antarctica was severed. If Chronomyrmex cannot be dismissed as a stem group taxon convergent on the morphology of Anonychomyrma, the details of this dispersal event must be reconsidered.

Modern dolichoderines inhabit a broad range of habitats, including soil, dead wood, and arboreal nesting (Shattuck 1992). Given their presence in Canadian amber, an arboreal habitat seems likely for the fossil specimens: something must have brought them into contact with resin at a relatively high frequency. Although there is nothing in their morphology that would strongly suggest an arboreal association, the paratype specimen of $C$. medicinehatensis (UASM 336802) is disarticulated and partially tangled in spider web, alongside a few frass pellets that appear to be composed of woody material, and a poorly-preserved nematoceran fly. The presence of such an association in an otherwise clean piece of amber (not clouded by particulates or litter fragments) would support its interpretation as a fragment of aerial web, and likely arboreal in origin. Given the limited evidence available at present, the habitat of the fossil specimens will remain speculative until more informative specimens are recovered.
Interestingly, Moreau et al. (2006) suggested that the majority of the dolichoderine radiation took place at around the same time as the rise of angiosperms and that this was likely the result of the increase in herbivorous insect diversity or increased variety of forest floor habitats that coincided with the plant diversification. Although the new fossil evidence suggests a need for a revised divergence timeline within the Dolichoderinae, it may actually strengthen the case for overlap between the windows of angiosperm and formicid diversification. If Chronomyrmex nests within the clade Leptomyrmecini, many of the nodes that are pushed back in time will fall directly within the main window of diversification proposed by Moreau et al. (2006).

\section{Acknowledgements}

We thank Shane and Vicki Leuck, and Mark Elaschuk for donating some of the amber specimens described herein, Danny Shpeley and Felix Sperling for their assistance with the UASM collections; and Brandon Strilisky for assistance the TMP collections. We are grateful for the critical comments and suggestions made by the reviewers David Grimaldi, André Nel, and Vincent Perrichot. Partial support was provided by U.S. National Science Foundation grants DEB-0542909 (to M.S. Engel). The participation of RCM was supported by a Natural Sciences and Engineering Research Council of Canada Postdoctoral Fellowship (to R.C. McKellar). This is a contribution of the Division of Entomology, University of Kansas Natural History Museum. 


\section{References}

Bolton, B. 1994. Identification guide to the ant genera of the world. 232 pp. Harvard University Press, Cambridge.

Bolton, B. 2003. Synopsis and classification of Formicidae. Memoirs of the American Entomological Institute 71, 1-370.

Bolton, B. 2012. AntCat: an online catalog of the ants of the world. Available from: www.antcat.org (accessed 28 January, 2013).

Brady, S.G., Schultz, T.R., Fisher, B.L. \& Ward, P.S. 2006. Evaluating alternative hypotheses for the early evolution and diversification of ants. Proceedings of the National Academy of Sciences 103(48), 18172-18177.

DOI 10.1073/pnas.0605858103

Brandão, C.R.F., Baroni Urbani, C., WAgEnSBERG, G. \& Yamaмото, C.I. 1998. New Technomyrmex in Dominican amber (Hymenoptera, Formicidae), with a reappraisal of Dolichoderinae phylogeny. Entomologica Scandinavica 29, 411-428. DOI 10.1163/187631298X00041

Carpenter, F.M., Folsom, J.W., Essig, E.O., Kinsey, A.C., Brues, C.T., Boesel, M.W. \& Ewing, H. 1937. Insects and arachnids from Canadian amber. University of Toronto Studies, Geological Series 40, 7-62.

DLussky, G.M. 1975. Superfamily Formicoidea Latreille, 1802. Family Formicidae Latreille, 1802, 114-122. In RASNITSYN, A.P. (ed.) Hymenoptera Apocrita of the Mesozoic. Transactions of the Paleontological Institute Academy of Sciences, USSR 147. [in Russian]

Dlussky, G.M. 1987. New Formicoidea (Hymenoptera) of the Upper Cretaceous. Paleontologicheskii Zhurnal 1, 131-135. [in Russian, English translation in 1988, Paleontological Journal 21, 146-150]

Dlussky, G.M. 1999. New ants (Hymenoptera, Formicidae) from Canadian amber. Paleontologicheskii Zhurnal 4, 73-76. [in Russian, English translation in 1999, Paleontological Journal 4, 409-412]

Dlussky, G.M. \& Rasnitsyn, A.P. 2002. Ants (Hymenoptera: Formicidae) of Formation Green River and some other Middle Eocene deposits of North America. Russian Entomological Journal 4, 411-436.

Dlussky, G.M. \& RASNitsyn, A.P. 2007. Paleontological record and stages of ant evolution. Uspekhi sovremennoi biologii 127, 118-134.

EMERY, C. 1913 (“1912”). Hymenoptera. Fam. Formicidae. Subfam. Dolichoderinae. Genera Insectorum 137, 1-50.

ENGEL, M.S. \& GRIMALDI, D.A. 2005. Primitive new ants in Cretaceous amber from Myanmar, New Jersey and Canada (Hymenoptera: Formicidae). American Museum Novitates 3485, $1-23$.

DOI 10.1206/0003-0082(2005)485[0001:PNAICA]2.0.CO;2

FoREL, A. 1878. Études myrmécologiques en 1878 (première partie) avec l'anatomie du gésier des fourmis. Bulletin de la Société Vaudoise des Sciences Naturelles 15, 337-392.

Goulet, H. \& Huber, J.T. (eds) 1993. Hymenoptera of the World: an Identification Guide to Families. 668 pp. Research Branch Agriculture Canada Publication, Ottawa.
Grimaldi, D. \& Agosti, D. 2000. A formicine in New Jersey Cretaceous amber (Hymenoptera: Formicidae) and early evolution of the ants. Proceedings of the National Academy of Sciences 97(25), 13678-13683.

DOI 10.1073/pnas.240452097

Grimaldi, D.A., Agosti, D. \& Carpenter, J.M. 1997. New and rediscovered primitive ants (Hymenoptera: Formicidae) in Cretaceous amber from New Jersey, and their phylogenetics relationships. American Museum Novitates 3208, 1-43.

Grimaldi, D.A. \& Engel, M.S. 2005. Evolution of the insects. 772 pp. Cambridge University Press, New York.

Grimaldi, D.A. \& Nascimbene, P.C. 2010. Raritan (New Jersey) amber, 167-191. In PEnNey, D. (ed.) Biodiversity of fossils in amber from the major world deposits. Siri Scientific Press, Manchester.

GRIMALDI, D., SHEDRINSKY, A. \& WAMPLER, T.P. 2000. A remarkable deposit of fossiliferous amber from the Upper Cretaceous (Turonian) of New Jersey, 1-76. In GrimaLdi, D. (ed.) Studies on Fossils in Amber, with Particular Reference to the Cretaceous of New Jersey. Backhuys Publishers, Leiden.

Hölldobler, B. \& Wilson, E.O. 1990. The ants. 732 pp. Harvard University Press, Cambridge.

KeLLER, R.A. 2011. A phylogenetic analysis of ant morphology (Hymenoptera: Formicidae) with special reference to the poneromorph subfamilies. Bulletin of the American Museum of Natural History 355, 1-90. DOI 10.1206/355.1

LaPolla, J.S., Dlussky, G.M. \& Perrichot, V. 2013. Ants and the fossil record. Annual Review of Entomology 58, 609-630. DOI 10.1146/annurev-ento-120710-100600

LATREILLE, P.A. 1809. Genera crustaceorum et insectorum secundum ordinem naturalem in familias disposita, iconibus exemplisque plurimus explicata. Tomus 4.399 pp. A. Koenig, Parisiis et Argentorati [= Paris \& Strasbourg].

McKellar, R.C. \& EnGel, M.S. 2012. Hymenoptera in Canadian Cretaceous amber (Insecta). Cretaceous Research 35, 258-279. DOI 10.1016/j.cretres.2011.12.009

McKellar, R.C., Glasier, J. \& Engel, M.S. 2013. A new trapjawed ant (Hymenoptera: Formicidae: Haidomyrmecini) from Canadian Late Cretaceous Amber. The Canadian Entomologist, 1-12. DOI 10.4039/tce.2013.23

McKellar, R.C. \& Wolfe, A.P. 2010. Canadian amber, 149-166. In PenNey, D. (ed.) Biodiversity of fossils in amber from the major world deposits. Siri Scientific Press, Manchester.

McKellar, R.C., Wolfe, A.P., Tappert, R. \& Muehlenbachs, K. 2008. Correlation between Grassy Lake and Cedar Lake ambers using infrared spectroscopy, stable isotopes, and palaeoentomology. Canadian Journal of Earth Sciences 45, 1061-1082.

DOI 10.1139/E08-049

Moreau, C.S., Bell, C.D., Vila, R., Archibald, S.B. \& Pierce, N.E. 2006. Phylogeny of the ants: diversification in the age of angiosperms. Science 312, 101-104.

DOI 10.1126/science.1124891

Nascimbene, P. \& Silverstein, H. 2000. The preparation of frag- 
ile Cretaceous ambers for conservation and study of organismal inclusions, 93-102. In GRIMALdI, D.A. (ed.) Studies on fossils in amber, with particular reference to the Cretaceous of New Jersey. Backhuys Publishers, Leiden.

Perrichot, V., Lacau, S., Néraudeau, D. \& Nel, A. 2008. Fossil evidence for the early ant evolution. Naturwissenschaften 95, 85-90. DOI 10.1007/s00114-007-0301-8

Perrichot, V., Néraudeau, D. \& Tafforeau, P. 2010. Charentese amber, 192-207. In Penney, D. (ed.) Biodiversity of Fossils in Amber from the Major World Deposits. Siri Scientific Press, Manchester.

PIKE, E.M. 1994. Historical changes in insect community structure as indicated by hexapods of Upper Cretaceous Alberta (Grassy Lake) amber. The Canadian Entomologist 126, 695-702. DOI 10.4039/Ent126695-3

PIKE, E.M. 1995. Amber taphonomy and the Grassy Lake, Alberta, amber fauna. 264 pp. PhD thesis, Department of Biological Sciences, The University of Calgary, Calgary.

RASNITSYN, A.P. \& KULICKA, R. 1990. Hymenopteran insects in Baltic amber with respect to the overall history of the order. Prace Muzeum Ziemi 41, 53-64.

Schmidt, A.R., Perrichot, V., Svojtkad, M., Anderson, K.B., Belete, K.H., Bussert, R., Dörfelth, H., Jancke, S., Mohr, B., Mohrmann, E., Nascimbene, P.C., Nel, A., Nel, P., Ragazzi, E., Roghi, G., Saupe, E.E., Schmidt, K., Schneider, H., Selden, P.A. \& VÁvra, N. 2010. Cretaceous African life captured in amber. Proceedings of the National Academy of
Sciences 107(16), 7329-7334.

DOI 10.1073/pnas.1000948107

ShatTUCK, S.O. 1992. Generic revision of the ant subfamily Dolichoderinae (Hymenoptera: Formicidae). Sociobiology 21(1), 1-181.

Shatтuck, S.O. 1995. Generic-level relationships within the ant subfamily Dolichoderinae (Hymenoptera: Formicidae). Systematic Entomology 20, 217-228.

DOI 10.1111/j.1365-3113.1995.tb00093.x

TYrReLl, J.B. 1892. Report on northwestern Manitoba with portions of the adjacent districts of Assiniboia and Saskatchewan. Annual Report of the Geological Survey Branch of Canada 5(1), 14-15.

WARD, P.S. 2007. Phylogeny, classification, and species-level taxonomy of ants (Hymenoptera: Formicidae). Zootaxa 1668, 549-563.

Ward, P.S., Brady, S.G., Fisher, B.L. \& Schultz, T.R. 2010. Phylogeny and biogeography of Dolichoderine ants: effects of data partitioning and relict taxa on historical inference. Systematic Biology 59(3), 342-362.

DOI 10.1093/sysbio/syq012

Wilson, E.O., Carpenter, F.M. \& Brown, W.L. JR. 1967. The first Mesozoic ants, with the description of a new subfamily. Psyche 74, 1-19. DOI 10.1155/1967/89604

Yoshimura, M. \& Fisher, B.L. 2011. A revision of male ants of the Malagasy region (Hymenoptera: Formicidae): Key to genera of the subfamily Dolichoderinae. Zootaxa 2794, 1-34. 